\title{
Influence on Different Types of Mycorrhizal Fungi on Crop Productivity in Ecosystem
}

\author{
K. Ramakrishnan, G. Bhuvaneswari* \\ Department of Botany, Annamalai University, Tamil Nadu- India. \\ *E-mail address: bhuvanalakshmi25@gamil.com
}

Keywords: Mycorrhizal Fungi; Crop Productivity; Ecosystem

\begin{abstract}
Mycorrhizal fungi greatly enhanced the ability of plants to take up phosphorus and other nutrients those are relatively immobile and exist in low concentration in the soil solution. Fungi can be important in the uptake of other nutrients by the host plant. Mycorrhizae establish symbiotic relationships with plants and play an essential role in plant growth, disease protection, and overall soil quality. Of the seven types of mycorrhizae described in current scientific literature (arbuscular, ecto, ectendo, arbutoid, monotropoid, ericoid and orchidaceous mycorrhizae), the arbuscular and ectomycorrhizae are the most abundant and widespread. This chapter presents an overview of current knowledge of mycorrhizal interactions, processes, and potential benefits to society. The molecular basis of nutrient exchange between arbuscular mycorrhizal (AM) fungi and host plants is presented; the role of AM fungi in disease protection, alleviation of heavy metal stress and increasing grain production. Most land plants form associations with mycorrhizal fungi. Mycorrhizas are mutualistic associations between fungi and plant roots. They are described as symbiotic because the fungus receives photo synthetically derived carbon compounds and the plant has increased access to mineral nutrients and sometimes water.
\end{abstract}

\section{INTRODUCTION}

In 1885 Albert Bernard Frank (Frank, 1885), in his study of soil microbial-plant relationships, introduced the Greek term 'mycorrhiza', which literally means 'fungus roots'. Mycorrhizal fungi have a close symbiotic relationship with plant roots. Mycorrhizal fungi colonize the plant's root system and develop a symbiotic association called "mycorrhiza". They form a network of fine filaments that associate with plant roots and draw nutrients and water from the soil that the root system would not be able to access otherwise. They are called mycorrhizae from the Greek "mukés", meaning fungus, and "rhiza," meaning roots Mycorrhizae are formed with more than 90\% of plant species. This fungus-plant alliance stimulates plant growth and accelerates root development. The success of mycorrhizal evolution has been attributed to the role that Mycorrhizal fungi play in the capture of nutrients from the soil of all ecosystems (Bonfante and Perotto, 2000).

This term was first used by Frank, a German Plant Pathologist in 1855 to describe the symbiotic relationship between plant roots and fungi. Mycorrhizal fungi differ from other plantfungus associations because of their ability to create an interface for nutrient exchange which occurs within living cells of the plant (Brundrett, 2004; Brundrett, 2002).

\section{TYPES OF MYCORRHIZAE}

There are two major groups of mycorrhizal fungi: ectomycorrhizal and endomycorrhizal fungi. Members of the former group develop exclusively on the exterior of root cells, whereas those of the latter penetrate the plant cells where direct metabolic exchanges can occur. Ectomycorrhizae are essentially found on trees and form visible structures whereas endomycorrhizal fungi colonize trees as well as shrubs and most herbaceous plants and do not form visible structures.

\section{Endomycorrhiza}

Endomycorrhizas form associations with most plants (approximately 80 percent of all plant species). These fungi cannot be grown in pure culture but must be grown in association with plant roots. They form branched structures called arbuscules within the host's root cells, and thus they are 
known as arbuscular mycorrhizal fungi. The arbuscules are sites of nutrient exchange between the fungus and the host. This manual focuses on arbuscular mycorrhizal fungi. Fungi of the endomycorrhizae consist of aseptet hyphae are members of the Phycomycetes and Basidiomycetes. The hyphae of these fungi penetrate the cells of the root cortex forming an internal hyphae network. Some hyphae also extend into the soil. For many plant species including most agricultural crops the predominant type of fungal infection is vesicular arbuscular mycorrhizae (VAM). This name derives from the occurrence of two types of structures characteristics of the fungi belongs to the family Endogonaceae i.e. arbuscules (Arbuscules are finely-branched structures that form within a cell and serve as a major metabolic exchange site between the plant and the fungus) and Vesicles (sac-like structures, emerging from hyphae, which serve as storage organs for lipids). These structures are similar to haustoria but are produced by dichotomous branching of hyphae. The AM fungi are the most common and widespread group. $80 \%$ of plants have endomycorrhizae association.

\section{ECTOMYCORRHIZAE}

Ectomycorrhizal fungi are also found in natural environments, mainly in forests ecosystems. These fungi can form visible reproductive structures (mushrooms) at the feet of trees they colonize. Ectomycorrhizal fungi grow between root cells without penetrating them. Their hyphae grow externally, forming dense growth known as a fungal mantle. These fungi form symbiotic relationships with most pines, spruces and some hardwood trees including beech, birch, oak and willow, 5 to $7 \%$ of plants belong to this association.

\section{How does mycorrhizal function}

Mycorrhizal fungus hyphae are considered to function primarily by increasing the soil volume from which available forms of nutrients are absorbed and provided to roots.

Fungal hyphae release enzymes (chitinase, peroxidase, cellulase, and protease), which allows them to digest and penetrate substrates.

Secretion of enzymes breaks down tough organic substrates that can then be absorbed and used by the fungus and/or host plant as energy and nutrient sources for growth and reproduction.

\section{Benefits of fungi}

Mycorrhizal fungi allow plants to draw more nutrients and water from the soil. They also increase plant tolerance to different environmental stresses. Moreover, these fungi play a major role in soil aggregation process and stimulate microbial activity. According to the plant species and to the growing practices and conditions, mycorrhizae provide different benefits to the plants and to the environment:

Increase plant establishment and survival at seeding or transplanting

Increase yields and crop quality

Improve drought tolerance, allowing watering reduction

Enhance flowering and fruiting

Optimize fertilizers use, especially phosphorus

Increase tolerance to soil salinity

Reduce disease occurrence

Contribute to maintain soil quality and nutrient cycling

\section{BENEFITS TO PLANTS}

\section{Supply of inorganic mineral nutrients}

Many thousands of experiments have shown that mycorrhizal fungi can overcome nutrient limitation to plant growth by enhancing nutrient acquisition, especially phosphorus (Marschner and Dell, 1994; Clark and Zeto, 2000). Most studies have investigated P, but mycorrhizas have been implicated in the uptake of most essential nutrients. The main mechanisms for an increase in inorganic nutrient uptake in mycorrhizal plants are: 


\section{Nutrient uptake sites in AM hyphae are discussed by Bago (2000).}

There is good evidence that some inorganic and organic nutrients may pass via the mycelia network from one host plant to another, but the significance of this has not been adequately quantified in the field.

\section{Supply of organic mineral nutrients}

Although many mycorrhizal fungi can access inorganic forms of N (Chalot and Brun, 1998) and P (Koide and Kabir, 2000), the relative importance of these modes of nutrition have yet to be quantified in the field. Some litter-inhabiting ECM fungi produce proteases and distribute soluble amino compounds through hyphal networks into the root (Read et al., 1989). Recently, Glomus has been shown to transport the amino acids glycine and glutamine into wheat (Hawkins et al., 2000).

In an extreme case Glomus intraradices delivered $100 \%$ of plant P to AM tomato. Such findings mean that the contribution of the direct pathway is decreased, often markedly so (see Smith et al. 2011, Smith and Smith 2011b), and highlight a highly significant role for the fungi, not only in P uptake via the AM pathway but also in reducing the contribution of the direct root pathway. The mobility of sequestered phosphate is reduced and, as a consequence, plant uptake rapidly exhausts the phosphate available in the vicinity of the root system and creates a localized depletion zone (Bucher, 2007). Potassium plays a key role in plant metabolism. It is essential for (1) activating a range of enzymatic reactions such as during the formation of pyruvate, (2) stomatal activities, (3) protein synthesis at the time of tRNA binding to the ribosome's (Blaha et al. 2000), and (4) maintaining osmotic pressure of the vacuole and cell turgor (Maathuis 2009; Evelin et al. 2012).

\section{Heavy metal uptake by AMF}

Arbuscular mycorrhizae have often been reported to sequester and to accumulate metals in their biomass as well as in the roots of host plants (Burke et al., 2000; Joner et al., 2000; Leyval and Joner, 2001; Gadd, 2005; Martin et al., 2007). It is reported that intracellular and extraradical mycelium of AM and ectomycorrhizal (ECM) fungi would have potential for metal sorption (Marschner et al., 1998; Joner et al., 2000). Recently, much evidence indicates that AMF exhibit great activity in the mobilization of metals that are bound by soil components (Leyval and Joner, 2001; Gadd, 2005; Göhre and Paszkowski, 2006).

\section{Effect of AMF on plant pathogens}

AMF may impact crop growth by affecting some soil microbial populations also present in the agro ecosystems. Many researches focused on these relationships, showing that interactions between AMF and other soil microorganisms can be either detrimental or favourable to plant pathogens, other rhizosphere microbes, AMF or to mycorrhizal plants (Meyer and Linderman, 1986a, b; Paulitz and Linderman, 1989; Calvet et al., 1992; St- Arnaud et al., 1995; Rousseau et al., 1996; Filion et al., 1999; Vigo et al., 2000; Elsen et al., 2001; Talavera et al., 2001; Gryndler et al., 2002; St- Arnaud and Elsen, 2005).

\section{AMF on plant beneficial microorganisms}

Several types of microorganisms like N2-fixing bacteria (de Varennes and Goss, 2007; Powell et al., 2007), P- solubilising bacteria and fungi (Barea et al., 2002), antagonist of plant pathogens (Budi et al., 1999) and soil aggregating bacteria (Rillig et al., 2005) are associated with the rhizosphere of mycorrhizal plants. These organisms are generally grouped under the name 'plant growth promoting rhizosphere microorganisms' (PGPR) because they are able to exert beneficial effects on plant growth. Growth and productivity of the legumes were always dependent on the combination of selected AMF and rhizobia, revealing that positive interactions between compatible symbionts could significantly increase growth and yields. Pot experiments done with soybean demonstrated that under controlled environment conditions, N2-fixation in mycorrhizal plants is generally greater than in non-mycorrhizal plants, with more nodules and greater nodule dry weight 
(Goss and de Varennes, 2002). However, it seems that under field conditions N2-fixation is not always promoted even if the tripartite symbiosis formed by indigenous arbuscular mycorrhizae, Bradyrhizobium and soybean is established (Antunes et al., 2006).

\section{AMF and crop productivity}

Daei et al (2009) concluded that the AM species have significant effect on root colonization of different wheat cultivars. Higher root colonization by Glomus etunicatum and G. mosseae relative to $G$. intraradices resulted in increased nutrient uptake and less $\mathrm{Na}+$ and $\mathrm{Cl}^{-}$adsorption by plant, and hence, increased plant growth under salinity. The combined inoculation of $\mathrm{PSB}+\mathrm{VAM}+$ Azotobacter in sunflower recorded higher plant height and total chlorophyll content and also significantly increased yield attributes, viz. thalamus diameter, weight of thalamus, filled seeds capitulum-1, and 100 seed weight (g), as well as seed and biological yield and oil content as compared to PSB+Azotobacter and VAM+Azotobacter inoculation (Patra et al, 2013).

Crop management involves a range of practices which can impact on the AM association, both directly, by damaging or killing AMF and indirectly, by creating conditions either favourable or unfavourable to AMF. Reducing tillage has been repeatedly shown to increase AM colonisation and nutrient uptake. Galvez et al (2001) compared mouldboard ploughed soils with chisel disked and no-till soil. AMF spore numbers and colonisation of maize roots was highest in the no-till system (though phosphorus use efficiency was highest under the mouldboard plough system). Mycorrhizal plants often have greater tolerance to drought than nonmycorrhizal plants. This study was conducted to determine the effects of arbuscular mycorrhizal (AM) fungi inoculation on growth, grain yield and mineral acquisition of two winter wheat (Triticum aestivum L.) cultivars grown in the field under well watered and water-stressed conditions by Al-karaki (2004). Wheat seeds were planted in furrows after treatment with or without the AM fungi Glomus mosseae or G. etunicatum. Roots were sampled at four growth stages (leaf, tillering, heading and grain-filling) to quantify AM fungi.

\section{Value to People}

In many upland forest regions of SE Asia, sporocarps of fungi, mostly basidiomycetes, have traditionally been collected for local consumption and trade (Dell et al., 2000). Many of these fungi, especially members of the Amanitaceae, Boletaceae, Russulaceae, and Tricholomataceae, form ectomycorrhizal associations with trees in the family's Dipterocarpaceae, Fagaceae and Pinaceae and are important for maintaining ecosystem function. The highest diversity of edible fungi is collected from mixed forests in China and the lowest diversity from areas of tropical pine and dipterocarps. In general, traded fresh sporocarps are 2 to 20 times more valuable, by weight, than local seasonal fruits and vegetables. International trade in a small number of species is having a major impact on the quality and sustainability of the mushroom harvest from some collecting sites. Forest fungi are also valued for medicine, for their aethetics, as bio-indicators of environmental quality and for bio-remediation.

\section{CONCLUSIONS}

Mycorrhizal fungi are now known to provide a wide range of significant benefits to their plant hosts. In addition to enhancing mineral nutrition, they induce greater resistance to soil pathogens, enhance tolerance to drought stress, and reduce sensitivity to toxic substances occurring in the soil. Introduction of mycorrhizal fungi do not appear to offer much advantage to enhanced nutrition or disease resistance in native species. Optimization of the ability of native fungi to colonize hosts in their natural habitat or to minimize loss of these fungi with disturbance is required. Highly dependent crop hosts should be selected over mycorrhizal- independent hosts in crop rotations or in multiple cropping systems. Traditional methods of breeding and producing crop plants in soils with high nutrient contents may select against the most efficient fungal communities or even against the mycorrhizal association. Many efforts have been made in recent years to accrue benefits from mycorrhizae for agriculture, horticulture, forestry, and site remediation. The results have been consistently positive, with some difficulties due to complications from diverse variables under field 
conditions. Mycorrhizal interactions between plants, fungi, and the environment are complex and often inseparable. Mycorrrhizae are an essential below-ground component in the establishment and sustainability of plant communities, but thorough knowledge is required to achieve maximum benefits from these microorganisms and their associations.

\section{Reference:}

[1] Al-Karaki, McMichael G,Zak B. Field response of wheat to arbuscular mycorrhizal fungi and drought stress. Mycorrhiza 14: 263-269 (2004).

[2] Antunes, P.M., de Varennes, A., Zhang, T., and Goss, M.J., 2006, the tripartite symbiosis formed by indigenous arbuscular mycorrhizal fungi, Bradyrhizobium japonicum and soya bean under field conditions. J. Agr. Crop Sci. 192: 373-378.

[3] Bago, B. 2000. Putative sites for nutrient uptake in arbuscular mycorrhizal fungi. Plant and Soil 226: 263-274.

[4] Barea, J.M., Azcón, R., and Azcón-Aguilar, C., 2002, Mycorrhizosphere interactions to improve plant fitness and soil quality. Antonie van Leeuwenhoek 81: 343-351.

[5] Blaha G, Stelzl U, Spahn CMT, Agrawal RK, Frank J, Nierhaus KH (2000) Preparation of functional ribosomal complexes and effect of buffer conditions on tRNA positions observed by cryoelectron microscopy. Meth Enzymol 317:292-309.

[6] Bucher, M., 2007, Functional biology of plant phosphate uptake at root and mycorrhiza interfaces. New Phytol. 173: 11-26.

[7] Budi, S.W., van Tuinen, D., Martinotti, G., and Gianinazzi, S., 1999, Isolation from the Sorghum bicolor mycorrhizosphere of a bacterium compatible with arbuscular mycorrhiza development and antagonistic towards soilborne fungal pathogens. Appl. Environ. Microbiol. 65: 5148-5150.

[8] Burke, S.C., Angle, J.S., Chaney, R.L., and Cunningham, S.D., 2000, Arbuscular mycorrhizae effects on heavy metal uptake by corn. Intern. J. Phytorem. 2: 23-29.

[9] Calvet, C., Barea, J.M., and Pera, J., 1992, In vitro interactions between the vesiculararbuscular mycorrhizal fungus Glomus mosseae and some saprophytic fungi isolated from organic substrates. Soil Biol. Biochem. 24: 775-780.

[10]Chalot, M., and A. Brun. 1998. Physiology of organic nitrogen acquisition by ectomycorrhizal fungi and ectomycorrhizas. FEMS Microbiology Reviews 22: 21-44.

[11]Clark, R.B., and S.K. Zeto. 2000. Mineral acquisition by arbuscular mycorrhizal plants. Journal of Plant Nutrition 23: 867-902.

[12]Daeia G, Ardekania M R,.Rejalic F, Teimurib S, Miransarid M. Alleviation of salinity stress on wheat yield, yield components and nutrient uptake using arbuscular mycorrhizal fungi under field conditions. J Plant Physio 166 : 617-625 (2009).

[13] de Varennes, A., and Goss, M.J., 2007, The tripartite symbiosis between legumes, rhizobia and indigenous mycorrhizal fungi is more efficient in undisturbed soil. Soil Biol. Biochem. 39: 2603-2607.

[14]Dell, B., N. Malajczuk, W. Dunstan, M.Q. Gong, Y.L. Chen, S. Lumyong, P. Lumyong, Supriyanto, and L. Ekwey. 2000. Edible forest fungi in SE Asia - Current practices and future management. Proceedings of International Workshop BIOREFOR, Nepal, 1999. p. 123-130.

[15]Elsen, A., Declerck, S., and De Waele, D., 2001, Effects of Glomus intraradices on the reproduction of the burrowing nematode (Radopholus similis) in dixenic culture. Mycorrhiza 11: 49-51. 
[16]Evelin H, Giri B, Kapoor R (2012) Contribution of Glomus intraradices inoculation to nutrient acquisition and mitigat ion of ionic imbalance in NaCl-stressed Trigonellafoenum-graecum. Mycorrhiza 22:203-217.

[17]Filion, M., St-Arnaud, M., and Fortin, J.A., 1999, Direct interaction between the arbuscular mycorrhizal fungus Glomus intraradices and different rhizosphere microorganisms. New Phytol. 141: 525-533.

[18]Gadd, G.M., 2005, Microorganisms in toxic metal-polluted soils, pp. 325-356. In F. Buscot and A. Varma (Eds.), Microorganisms in soils: Roles in genesis and functions. Part V. Book series: Soil biology, Vol. 3. Springer, Berlin/Heidelberg, Germany.

[19] Galvez L, Douds D D, Drinkwater Le and Wagoner P. Effect of tillage and farming system upon VAM fungus populations and mycorrhizas and nutrient uptake of maize Plant and Soil 228: 299-308 (2001).

[20] Göhre, V., and Paszkowski, U., 2006, Contribution of the arbuscular mycorrhizal symbiosis to heavy metal phytoremediation. Planta 223: 1115-1122.

[21]Goss, M.J., and de Varennes, A., 2002, Soil disturbance reduces the efficacy of mycorrhizal associations for early soybean growth and N2 fixation. Soil Biol. Biochem. 34: 1167-1173.

[22] Gryndler, M., Vosatka, M., Hrselova, H., Catska, V., Chvatalova, I., and Jansa, J., 2002, Effect of dual inoculation with arbuscular mycorrhizal fungi and bacteria on growth and mineral nutrition of strawberry. J. Plant Nutr. 25: 1341-1358.

[23] Hawkins, H.J., Johansen, A., and George, E., 2000, Uptake and transport of organic and inorganic nitrogen by arbuscular mycorrhizal fungi. Plant Soil 226: 275-285.

[24]Joner, E.J., Briones, R., and Leyval, C., 2000, Metal-binding capacity of arbuscular mycorrhizal mycelium. Plant Soil 226: 227-234.

[25]Koide, R.T., and Kabir, Z., 2000, extra radical hyphae of the mycorrhizal fungus Glomus intraradices can hydrolyse organic phosphate. New Phytol. 148: 511-517.

[26]Leyval, C., and Joner, E.J., 2001, Bioavailability of heavy metals in the mycorrhizosphere, pp. 165-185. In G.R. Gobran, W.W. Wenzel, and E. Lombi (Eds.), Trace elements in the rhizosphere. CRC, Boca Raton, FL.

[27] Maathuis FJM (2009) Physiological functions of mineral macro nutrients. Curr Opin Plant Biol $12: 250-258$.

[28] Marschner, P., Jentschke, G., and Godbold, D.L., 1998, Cation exchange capacity and lead sorption in ectomycorrhizal fungi. Plant Soil 205: 93-98.

[29] Marschner, H., and B. Dell. 1994. Nutrient uptake in mycorrhizal symbiosis. Plant and Soil 159: 89-102.

[30]Meyer, J.R., and Linderman, R.G., 1986a, Response of subterranean clover to dual inoculation with vesicular-arbuscular mycorrhizal fungi and a plant growth-promoting bacterium, Pseudomonas putida. Soil Biol. Biochem. 18: 185-190.

[31] Meyer, J.R., and Linderman, R.G., 1986b, Selective influence on populations of rhizosphere or rhizoplane bacteria and actinomycetes by mycorrhizas formed by Glomus fasciculatum. Soil Biol. Biochem. 18: 191-196.

[32] Martin, F., Perotto, S., and Bonfante, P., 2007, Mycorrhizal fungi: A fungal community at the interface between soil and roots, pp. 201-236. In R. Pinton, Z. Varanini, and P. Nannipieri (Eds.), The rhizosphere: Biochemistry and organic substances at the soil-plant interface. Marcel Dekker, New York. 
[33]Patra P, Pati BK, Ghosh GK, Mura SS, Saha A. Effect of Bio-fertilizers and Sulphur on Growth, Yield, and Oil Content of Hybrid Sunflower (Helianthus annuus. L) In a Typical Lateritic Soil. 2: 603 doi: 10.4172/scientific reports.603 (2013).

[34]Paulitz, T.C., and Linderman, R.G., 1989, Interactions between fluorescent pseudomonades Plant Pathol. 49: 509-514.

[35]Powell, J.R., Gulden, R.H., Hart, M.M., Campbell, R.G., Levy-Booth, D.J., Dunfield, K.E., Pauls, K.P., Swanton, C.J., Trevors, J.T., and Klironomos, J.N., 2007, Mycorrhizal and rhizobial colonization of genetically modified and conventional soybeans. Appl. Environ. Microbiol. 73: 4365-4367.

[36]Rillig, M.C., Lutgen, E.R., Ramsey, P.W., Klironomos, J.N., and Gannon, J.E., 2005, Microbiota accompanying different arbuscular mycorrhizal fungal isolates influence soil aggregation. Pedobiol. 49: 251-259.

[37]Rousseau, A., Benhamou, N., Chet, I., and Piché, Y., 1996, Mycoparasitism of the extrametrical phase of Glomus intraradices by Trichoderma harzianum. Phytopathology 86: 434-443.

[38] St-Arnaud, M., and Elsen, A., 2005. Interaction or arbuscular-mycorrhizal fungi with soil-borne pathogens and non-pathogenic rhizosphere micro-organisms. In: In vitro culture of mycorrhizas, S. Declerck, D.-G. Strullu and J. A. Fortin eds., Springer, Berlin/Heidelberg, Germany, pp. 217-231.

[39] St-Arnaud, M., Hamel, C., Vimard, B., Caron, M., and Fortin, J.A., 1995, Altered growth of Fusarium oxysporum f. sp. chrysanthemi in an in vitro dual culture system with the vesicular arbuscular mycorrhizal fungus Glomus intraradices growing on Daucus carota transformed roots. Mycorrhiza 5: 431-438.

[40] Supriyanto and L. Ekwey. 2000. Edible forest fungi in SE Asia - Current practices and future management. Proceedings of International Workshop BIOREFOR, Nepal, 1999. p. 123-130.

[41] Talavera, M., Itou, K., and Mizukubo, T., 2001, Reduction of nematode damage by root colonization with arbuscular mycorrhiza (Glomus spp.) in tomato-Meloidogyne incognita (Tylenchida: Meloidognidae) and carrot-Pratylenchus penetrans (Tylenchida: Pratylenchidae) pathosystems. Appl. Entomol. Zool. 36: 387-392.

[42] Vigo, C., Norman, J.R., and Hooker, J.E., 2000, Biocontrol of the pathogen Phytophthora parasitica by arbuscular mycorrhizal fungi is a consequence of effects on infection loci. Plant Pathol. 49: 509-514. 